\title{
Bisphosphonates antagonise bone growth factors' effects on human breast cancer cells survival
}

\author{
O Fromigue', N Kheddoumi' and J-J Body,,I \\ 'Laboratory of Endocrinology, Bone Diseases and Breast Cancer Research, Department of Medicine, Institut Jules Bordet, Université Libre de Bruxelles. \\ Rue Heger-Bordet, 11000 Brussels, Belgium
}

Bone tissue constitutes a fertile 'soil' for metastatic tumours, notably breast cancer. High concentrations of growth factors in bone matrix favour cancer cell proliferation and survival, and a vicious cycle settles between bone matrix, osteoclasts and cancer cells. Classically, bisphosphonates interrupt this vicious cycle by inhibiting osteoclast-mediated bone resorption. We and others recently reported that bisphosphonates can also induce human breast cancer cell death in vitro, which could contribute to their beneficial clinical effects. We hypothesised that bisphosphonates could inhibit the favourable effects of 'bone-derived' growth factors, and indeed found that bisphosphonates reduced or abolished the stimulatory effects of growth factors (IGFs, FGF-2) on MCF-7 and T47D cell proliferation and inhibited their protective effects on apoptotic cell death in vitro under serum-free conditions. This could happen through an interaction with growth factors' intracellular phosphorylation transduction pathways, such as ERKI/2-MAPK. In conclusion, we report that bisphosphonates antagonised the stimulatory effects of growth factors on human breast cancer cell survival and reduced their protective effects against apoptotic cell death. Bisphosphonates and growth factors thus appear to be concurrent compounds for tumour cell growth and survival in bone tissue. This could represent a new mechanism of action of bisphosphonates in their protective effects against breast cancer-induced osteolysis.

British Journal of Cancer (2003) 89, 178- 184. doi:10.1038/sj.bjc.6601009 www.bjcancer.com

(c) 2003 Cancer Research UK

Keywords: bisphosphonates; bone metastases; growth factor; breast cancer; apoptosis

Breast and prostate cancers most often metastasise to bone (Yoneda et al, 2000). A 'seed and soil' hypothesis (Paget, 1889) can explain this phenomenon. The bone extracellular matrix is rich in growth factors (Hauschka et al, 1986), which are released during the continuous remodelling process and favour cancer cell proliferation and survival (Barnes, 1988; Geier et al, 1992; Quinn et $a l, 1996)$. On the other hand, breast cancer cells are able to stimulate bone resorption by increasing osteoclast recruitment and proliferation as well as the activity of mature osteoclasts (Mundy, 1991; Taube et al, 1994; Yoneda et al, 2000). Bone microenvironment will then be even more enriched in bone-derived growth factors that enhance proliferation and survival of cancer cells. This sets up a vicious cycle between cancer cells, osteoclasts and bone matrix.

Bone metastases are responsible for considerable misery in cancer patients. Bisphosphonates reduce the skeletal morbidity rate in breast cancer patients with bone metastases by up to 40-50\% (Paterson et al, 1993; Body et al, 1998; Hortobagyi et al, 1998; Theriault et al, 1999; Body, 2001) and they can decrease the number and the extent of bone metastases in animal models of tumour-induced osteolysis (Hughes et al, 1995; Hiraga et al, 2001) as well as in patients treated in the adjuvant setting (Coleman, 2002; Powles et al, 2002).

Bisphosphonates are synthetic analogues of pyrophosphate in which the oxygen bridge is replaced by a carbon atom that allows the attachment of various side chains. Bisphosphonates are very

*Correspondence: Dr JJ Body; E-mail: jj.body@bordet.be Received 7 January 2003; revised 3 April 2003; accepted I 3 April 2003 stable compounds that exhibit a high affinity for calcified matrices such as hydroxyapatite in bone (Lin, 1996), and are successfully used as powerful inhibitors of increased bone resorption in several bone diseases (Fleisch, 1997a, b). They act by decreasing the recruitment, proliferation and differentiation of preosteoclasts (Lowik et al, 1988; Hughes et al, 1989; Nishikawa et al, 1996), their adhesion to the mineralised matrix and, most importantly, the resorptive activity of mature osteoclasts (Sato et al, 1991; Selander et al, 1994; Azuma et al, 1995; Murakami et al, 1995). They also shorten osteoclast lifespan by induction of programmed cell death (apoptosis) (Hughes et al, 1995). In addition, the inhibitory activity of bisphosphonates on bone resorption may be indirectly mediated by other cells such as cells of the osteoblastic lineage or the macrophage family (Sahni et al, 1993; Nishikawa et al, 1996; Vitte et al, 1996; Siwek et al, 1997; Fromigue and Body, 2002). On the other hand, we and others (Fromigue et al, 2000; Senaratne et al, 2000; Jagdev et al, 2001b) previously showed that bisphosphonates can induce human breast cancer cell death in vitro (apoptosis and/or necrosis), which could contribute to their beneficial clinical effects. Thus, bisphosphonates exhibit beneficial effects on bone integrity by reducing bone resorption induced by osteoclasts and maybe also by direct 'antitumoral' effects.

In cancer patients treated with bisphosphonates, metastatic breast cancer cells in bone are thus exposed to both bisphosphonates, which can induce their death, and to growth factors, which, in contrast, may stimulate their growth and survival. We investigated the effects of combinations of bisphosphonates and several 'bone-derived' growth factors on breast cancer cell survival to examine if bisphosphonates could also inhibit the stimulatory 
and protective effects of growth factors on breast cancer cells. Our data point to a possibly new mode of action of bisphosphonates in the process of breast cancer-induced osteolysis.

\section{MATERIALS AND METHODS}

\section{Materials}

Media, supplements and plastic culture materials were obtained from Life Technologies SA (Merelbeke, Belgium). Recombinant human insulin-like growth factor types I and II (IGF-I and -II), basic fibroblast growth factor (FGF-2) and epidermal growth factor (EGF) were purchased from R\&D Systems (Abingdon, Oxon, UK). Pamidronate (3-amino-1-hydroxypropylidene bisphosphonic acid) and zoledronic acid (2-imidazol-1-yl-1-hydroxyethylidene-1,1 bisphosphonic acid) were provided by Novartis (Basel, Switzerland). Zoledronic acid evidently becomes zoledronate in culture conditions, explaining why we used this last term thoughout the Results. Clodronate (dichloromethylene bisphosphonic acid) and ibandronate (1-hydroxy-3-methylpentylamino-propylidene bisphosphonic acid) were provided by Hoffmann-LaRoche (Basel, Switzerland). MTT (3-[4,5-dimethylthiazol-2-yl]-2,5-diphenyl tetrazolium bromide) reagent and rabbit anti- $\beta$-actin antibody were obtained from Sigma-Aldrich SA (Bornem, Belgium). Ac-IETD-AMC and Ac-DEVD-AMC were obtained from Pharmingen (ErembodegemAalst, Belgium). The 7-amino-4-methylcoumarin was from Bachem Feinchemikalien AG (Bubendorf, Switzerland). The mouse bax and bcl-2 antibodies were purchased from Santa Cruz Biotechnology (Santa Cruz, CA, USA). The phosphospecific antibodies anti-ERK1/2 MAPK, -p38 MAPK and -JNK were purchased from New England Biolabs Inc. (Beverly, MA, USA), and secondary antibodies conjugated with horseradish peroxidase were from Dako (Denmark).

\section{MTT test}

Subconfluent cells were washed twice in PBS before addition of phenol red-free and serum-free medium containing or not the indicated agents (bisphosphonates or growth factors). We previously tested and compared several techniques (MTT test, cell counting, total DNA content and BrdU incorporation) to investigate breast cancer cell survival under serum-free conditions. In this study, we used the MTT test as previously described, and all significant effects were validated by cell counting. We used six replicates for each condition and experiments were repeated at least three times. Results are means \pm s.e.m. of treated/control ratios.

\section{Caspase activity}

After 3,8, 15, 24 and $48 \mathrm{~h}$ of incubation under serum-free conditions, cells were trypsinised and processed as previously described (Fromigue et al, 2000). Briefly, caspases activities were assessed by the cleavage of synthetic fluorogenic substrates containing the amino-acid sequences IETD: Ile-Glu-Thr-Asp (caspase-8), or DEVD: Asp-Glu-Val-Asp (effector caspase -3, -6 and -7) combined to a fluorophore (AMC). MCF-7 cell line is known to be devoid of a caspase-3 activity (Janicke et al, 1998), which results in the determination of caspase-6 and -7 activities by the DEVD-AMC substrate. Results, obtained as nmol $\mathrm{AMCh}^{-1} 10^{-6}$ cells, are expressed as treated over control ratios.

\section{Western blotting}

Attached cells, collected by trypsinisation, were pooled with the

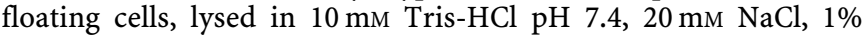
NP40, $0.5 \%$ deoxycholate $\mathrm{Na}$ and $0.1 \mathrm{~mm}$ PMSF for $30 \mathrm{~min}$ on ice and centrifuged. Proteins were separated on $12 \%$ SDS-PAGE and electrotransferred onto PVDF membranes. Filters were blocked in $10 \mathrm{~mm}$ Tris- $\mathrm{HCl} \mathrm{pH}$ 7.4, $150 \mathrm{~mm} \mathrm{NaCl}, 1 \mathrm{~mm}$ EDTA, 0.1\% Tween-20, $3 \% \mathrm{BSA}$ and $0.5 \%$ gelatin for $3 \mathrm{~h}$, then incubated overnight with primary antibody (1:500 for $\beta$-actin, $1: 1000$ for bax or bcl-2). Filters were washed twice before incubation for $1 \mathrm{~h}$ with the secondary antibody conjugated with horseradish peroxidase $(1: 2500)$. After three final washes, filters were exposed following the enhanced chemiluminescence detection reagent (Amersham, Les Ulis, France) to an autoradiographic film (Kodak, Vilvoorde, Belgium). For detection of the phosphorylation state of p38-, ERK1/2-MAPKs and JNK, subconfluent cells were washed twice in PBS before incubation with phenol red-free and serum-free medium containing bisphosphonates and/or growth factors. After $2,5,10$ or $30 \mathrm{~min}$, culture media were removed and flasks immersed in dry ice-cold methanol. Cell layers were then lysed as described above. Phospho-specific primary antibodies were used at the dilution $1: 2000$.

\section{Statistical analysis}

Statistical analysis was performed using classical statistical tests (package Super ANOVA; Macintosh, Abacus concepts Inc., Berkeley, CA, USA) with a statistical significance level at least $<0.05$ (Fisher's PLSD).

\section{RESULTS}

\section{Dose-response effects of growth factors on breast cancer cells}

Cell survival was assessed by the MTT test and all significant effects were validated by cell counting (see Materials and methods; data not shown). We checked the effects of four different growth factors on the viability under serum-free conditions of two classical breast cancer cell lines, namely MCF-7 and T47D. Exposure to IGF-I $\left(0.1-100 \mathrm{ng} \mathrm{m}^{-1}\right)$ or IGF-II $\left(1-1000 \mathrm{ng} \mathrm{ml}^{-1}\right)$ for $24 \mathrm{~h}$ increased cell survival in a dose-dependent manner. IGF-I induced a bell-shaped growth curve with a peak at $10 \mathrm{ng} \mathrm{ml}^{-1}$ (up to $+26 \%, P<0.005$; Figure $1 \mathrm{~A}$ ). Lower concentrations $\left(1-5 \mathrm{ng} \mathrm{ml}^{-1}\right)$ already significantly increased cell viability and
A

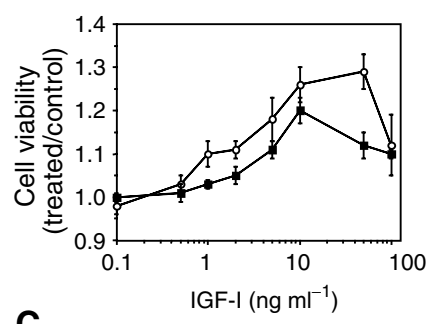

C

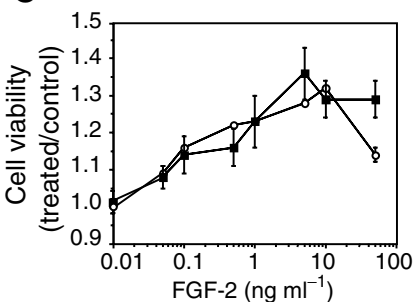

B

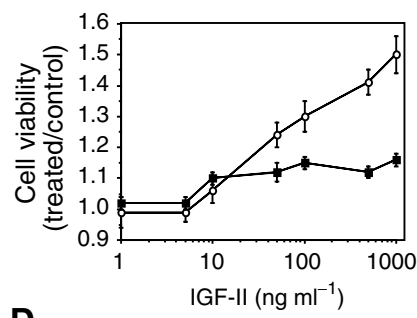

D

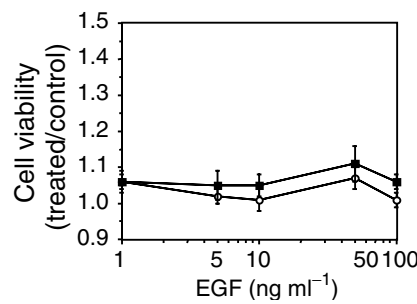

Figure I Modulation of breast cancer cell survival by growth factors. Breast cancer cells (O, MCF-7 and $\mathbf{\square}$, T47D) were incubated for $24 \mathrm{~h}$ under serum-free conditions, without or with increasing concentrations of IGF-I, IGF-II, FGF-2 or EGF. Cell viability was evaluated using the MTT test and expressed as treated over control ratios (means \pm s.e.m., $n=15-20$ ). 
concentrations above $50 \mathrm{ng} \mathrm{ml}^{-1}$ had lower stimulatory effects. Doses 10-50-fold higher were required for IGF-II to detect stimulatory effects comparable to IGF-I. In contrast to IGF-I, IGF-II did not exhibit a biphasic pattern, but dose-dependently increased MCF-7 cell survival, at least up to $1000 \mathrm{ng} \mathrm{ml}^{-1}$ ( $+50 \%$, $P<0.05$; Figure 1B). IGF-II also dose-dependently improved T47D cell survival and the stimulatory effects persisted for concentrations above $100 \mathrm{ng} \mathrm{ml}^{-1}$, then plateaud $(+15 \%, \quad P<0.05$; Figure 1B). These data confirm that IGFs can increase MCF-7 and T47D cell survival and indicate that IGF-II was about 10 -fold less potent than IGF-I in our model. FGF-2 dose-dependently increased MCF-7 and T47D cells survival (up to $+36 \%, P<0.05$; Figure 1C). Very low concentrations of $0.05 \mathrm{ng} \mathrm{ml}^{-1}$ increased cell viability by about $10 \%(P<0.02)$. The maximal stimulatory effect was observed for concentrations of $5-10 \mathrm{ng} \mathrm{ml}^{-1}$ for both cell lines $(+30 \%, P<0.001)$. Higher concentrations did not improve T47D nor MCF-7 cell viability. Lastly, EGF $\left(1-100 \mathrm{ng} \mathrm{ml}^{-1}\right)$ did not exert any significant effect on MCF-7 or T47D cell survival (Figure 1D). We thus did not further investigate the possible modulatory effects of bisphosphonates on the effects of this particular growth factor.

\section{Bisphosphonates inhibit growth factors' proliferative effects}

We then investigated the effects of bisphosphonates in combination with growth factors on breast cancer cell viability under serum-free conditions. Bisphosphonates were all tested at the concentration of $10^{-6} \mathrm{M}$ and inhibited cell viability by up to $27 \%$ in MCF-7 cells and by up to $36 \%$ in T47D cells (see Fromigué et al, 2000). IGF-I, IGF-II and FGF-2 were used at concentrations exhibiting optimal or suboptimal stimulatory effects, that is, $10 \mathrm{ng} \mathrm{ml}^{-1}$ for IGF-I, $100 \mathrm{ng} \mathrm{ml}^{-1}$ for IGF-II and $5 \mathrm{ng} \mathrm{ml}^{-1}$ for FGF2 (see Figure 1). In MCF-7 cells, the most impressive effects of bisphosphonates were observed with FGF-2 (Figure 2, upper panel) since all four bisphosphonates almost completely abolished the FGF-2 stimulatory effects ( $86-99 \%$ inhibition). The effects of IGFs were less inhibited by bisphosphonates (reduction of $20-68 \%$ of
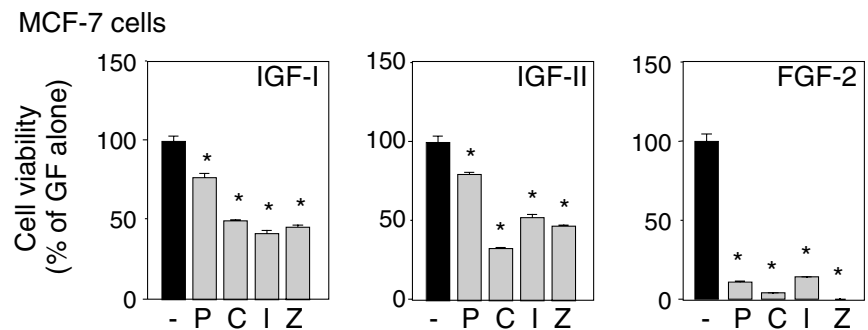

T47D cells
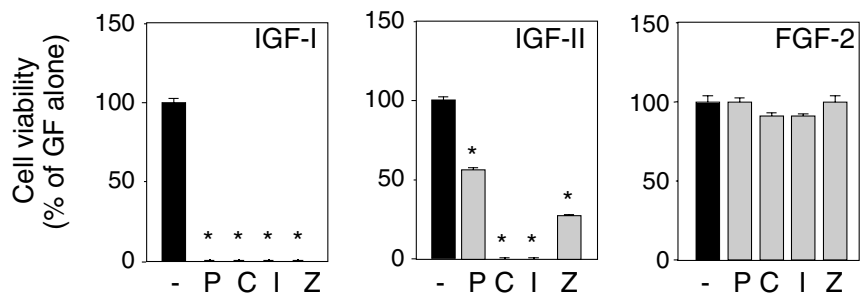

Figure 2 Bisphosphonates reduce growth factors' stimulatory effects on human breast cancer cell survival. MCF-7 cells (upper panel) and T47D cells (lower panel) were incubated for $24 \mathrm{~h}$ under serum-free conditions, in the presence of $10^{-6} \mathrm{M}$ pamidronate $(\mathrm{P})$, clodronate $(\mathrm{C})$, ibandronate $(\mathrm{I})$ or zoledronate $(Z)$, and of IGF-I $\left(10 \mathrm{ng} \mathrm{ml}^{-1}\right)$, IGF-II $\left(100 \mathrm{ng} \mathrm{ml^{-1 }}\right)$ or FGF-2 $\left(5 \mathrm{ng} \mathrm{ml}^{-1}\right)$. Cell viability was evaluated by the MTT test and expressed as the percentage of growth factors' effects alone (means \pm s.e.m., $n=18$ 20). *:P $<0.05$ vs growth factor alone. their proliferative effect). For the T47D cell line, we found a quite different pattern since FGF-2-treated cells were not affected by bisphosphonates (Figure 2, lower panel), whereas IGF-I effects were completely abolished by all four tested bisphosphonates. Clodronate and ibandronate also fully inhibited IGF-II stimulatory effects on T47D cell survival, whereas pamidronate and zoledronate partly reduced (by 43 and $72 \%$, respectively) IGF-II effects (Figure 2, lower panel). These data show that bisphosphonates can completely or partly inhibit growth factors' stimulatory effects on breast cancer cell survival. No marked differences could be noticed between the four bisphosphonates except that pamidronate was often the least potent compound.

\section{Differential effects of bisphosphonates and growth factors on apoptosis}

We previously reported that bisphosphonates reduce breast cancer cell survival by inducing both programmed cell death (apoptosis) and direct necrosis in the MCF-7 cell line, whereas necrosis is the main mechanism involved in the reduction of T47D cell survival (Fromigue et al, 2000). The bisphosphonate-induced apoptotic process in MCF-7 cells is characterised by a time-dependent activation of effector caspases. We investigated the modulation of the activity of initiator (caspase-8) and effector caspases (caspase-6 and -7) in MCF-7 cells incubated in the presence of bisphosphonates and growth factors. No modulation of caspase- 8 activity was detected in bisphosphonates and/or growth factors treated cells (data not shown). We found that neither IGF-I nor IGF-II nor FGF-2 significantly modified the basal levels of effector caspases activity in MCF-7 cells at any time (from 3 to $48 \mathrm{~h}$; data not shown). However, when a bisphosphonate and a growth factor were simultaneously added in MCF-7 cells culture medium, we found a marked reduction in bisphosphonate-induced stimulation of effector caspases activity (Figure 3). These data suggest that
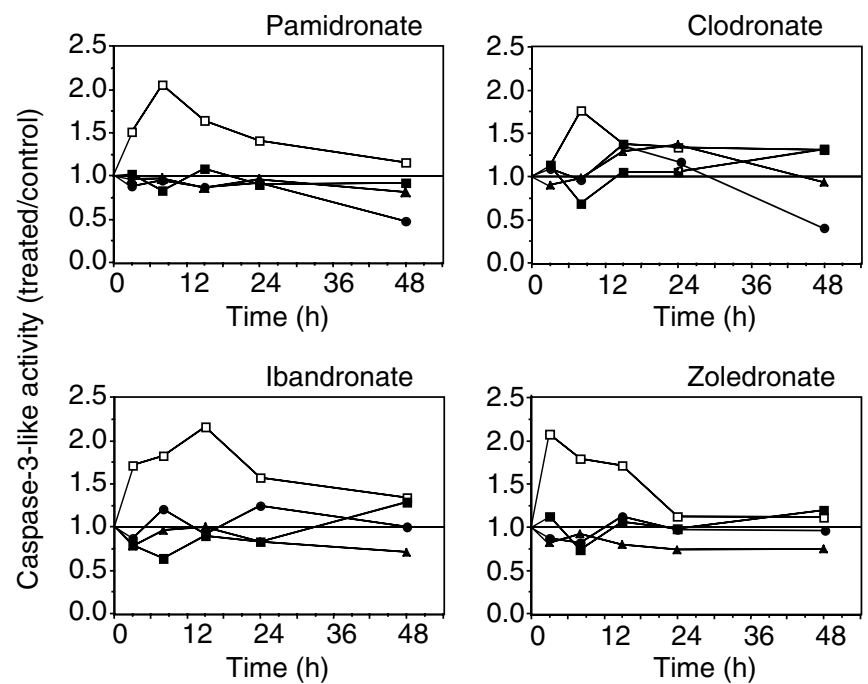

$$
\begin{aligned}
& \text {, Bisphosphonate alone } \\
& \text { घ, Bisphosphonate + IGF-I } \\
& \text {, Bisphosphonate + IGF-II } \\
& \text {-, Bisphosphonate + FGF-2 }
\end{aligned}
$$

Figure 3 Modulations of effector caspases activity in MCF-7 cells. Subconfluent MCF-7 cells were incubated in the presence of $10^{-6} \mathrm{M}$ bisphosphonates and IGF-I $\left(10 \mathrm{ng} \mathrm{ml}^{-1}\right)$, IGF-II $\left(100 \mathrm{ng} \mathrm{ml}^{-1}\right)$ or FGF-2 $\left(5 \mathrm{ng} \mathrm{m}^{-1}\right)$ for up to $48 \mathrm{~h}$. Effector caspases (caspase $\left.-6,-7\right)$ activity was determined at different time points using a synthetic fluorogenic substrate (DEVD-AMC, see Materials and methods). Results are shown as treated over control ratios $(n=3)$. 
growth factors could attenuate bisphosphonate-induced MCF-7 cells apoptosis by lowering the caspases induction.

Other intracellular effectors are involved in the induction of apoptosis. The ratio between proapoptotic proteins (such as bax) and antiapoptotic proteins (such as bcl-2) determines whether a cell will undergo apoptosis or will be protected from it (Adams and Cory, 1998). We investigated the effects of growth factors and of bisphosphonates, alone or in combination, on bax and bcl-2 protein levels in MCF-7 cells, and found that all four bisphosphonates increased the bax/bcl-2 ratio (Figure 4A) whereas IGF-I and FGF-2 significantly decreased the same ratio (Figure 4B). The effects of IGF-II were not significant. When bisphosphonates were combined with IGF-I or FGF-2, we observed a reduction in the antiapoptotic effect of growth factors on MCF-7 cells (Figure 4C). IGF-I protective effects were reduced by $50-100 \%(P<0.05)$ by bisphosphonates and the ones of FGF-2 by $19-75 \%(P<0.05)$. These data indicate that bisphosphonates could reduce the protective effects of growth factors on MCF-7 cell survival by significantly reducing their antiapoptotic potential.

A
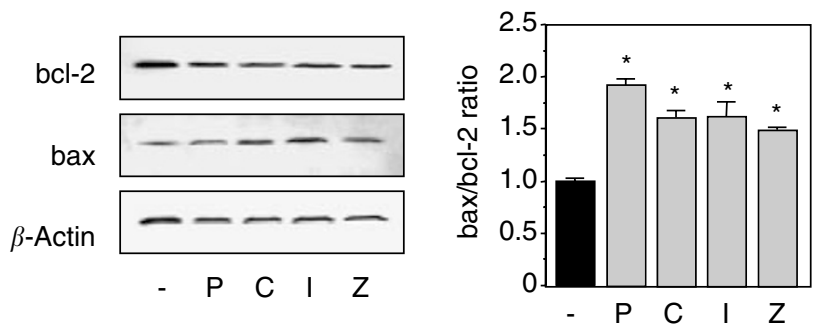

B
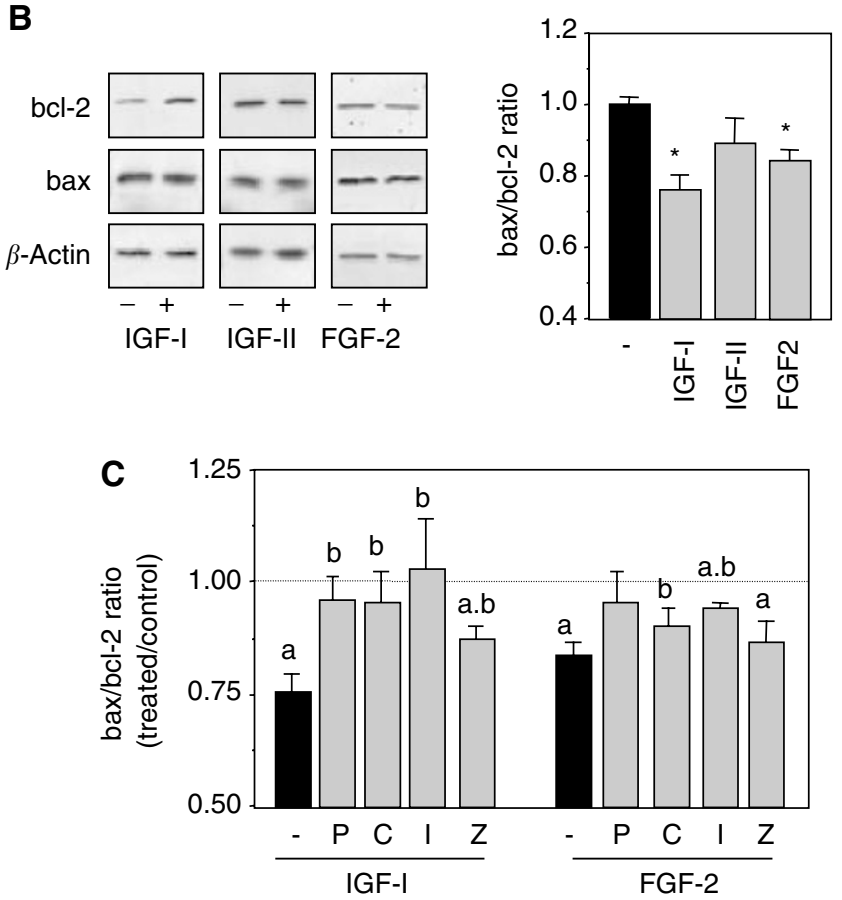

Figure 4 Modulations of the bax/bcl-2 ratio in MCF-7 cells. Subconfluent MCF-7 cells were incubated for $24 \mathrm{~h}$, under serum-free conditions, in the absence or presence of $10^{-6} \mathrm{M}$ pamidronate $(P)$, clodronate $(C)$, ibandronate (I), zoledronate (Z), $10 \mathrm{ng} \mathrm{ml}^{-1}$ IGF-l or $5 \mathrm{ng} \mathrm{ml}^{-1}$ FGF-2. $\mathrm{Bax}$ and bcl-2 expression levels were determined by Western blot and corrected for $\beta$-actin levels. Results are expressed as means \pm s.e.m. of the bax/bcl-2 ratio $(n=4-10)$. *:P<0.05 vs control. (A) Blots and derived ratios under bisphosphonates treatment. (B) Blots and derived ratios under growth factors treatments. (C) Relative intensity of signals under combinations of growth factors (IGF-I or FGF-2) and bisphosphonates. a: $P<0.05$ vs control; b: $P<0.05$ vs growth factor alone.

\section{Bisphosphonates and FGF-2 modulate cell survival} signalling pathways

Cell survival is classically upregulated by growth factors such as IGFs or FGF-2 via intracellular signalling pathways involving mitogen-activated protein kinases (MAPK) or stress-activated protein kinases (SAPK). We investigated by Western blotting the effects of bisphosphonates and/or growth factors on phosphorylation states of these kinases in MCF-7 breast cancer cells. No modulatory effects on p38-MAPK or JNK phosphorylation levels could be detected under bisphosphonates or/and growth factors treatments (data not shown). By contrast, IGFs weakly stimulated ERK1/2-MAPK phosphorylation (by about $10 \%$ after 5-10 min, data not shown), whereas FGF-2 induced a marked increase in ERK1/2-MAPK phosphorylation status (by a maximum of 2.3-fold compared to untreated cells after $10 \mathrm{~min}$; Figure 5). In contrast, all four bisphosphonates induced a slight decrease in phospho-ERK1/2 rates (by 7-16\%; Figure 5). When FGF-2 and bisphosphonates were combined, the effects of FGF-2 were markedly or completely inhibited $(P<0.05)$. These initial data suggest that bisphosphonates and FGF-2 can modulate in opposite directions the phosphorylation status of common signalling pathways such as MAPK, which is involved in the balance between induction of and protection against cell death.

A
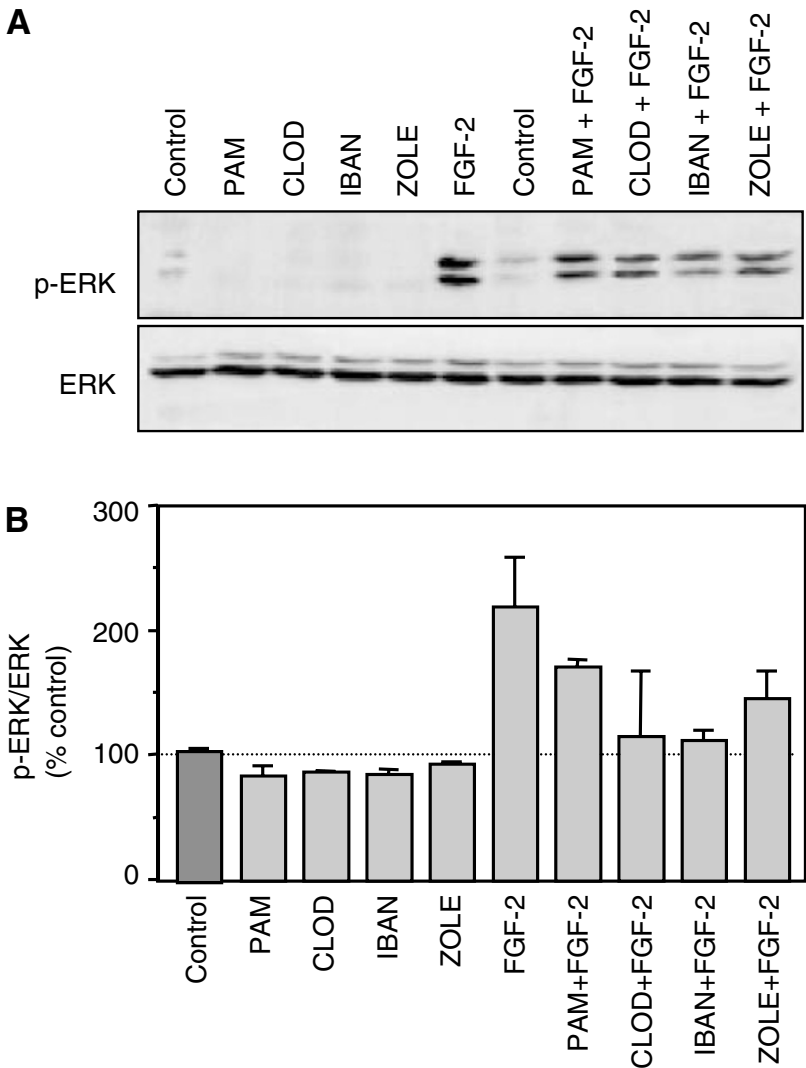

Figure 5 Modulation of the ERK-MAPK phosphorylation status in MCF-7 cells. (A) MCF-7 cells were incubated for $10 \mathrm{~min}$ with bisphosphonates $\left(10^{-6} \mathrm{M}\right)$ and/or FGF-2 $\left(5 \mathrm{ng} \mathrm{ml}^{-1}\right)$ in phenol red-free and serum-free medium. Cell lysates were analysed by Western blot for phospho-p42/p44 and total p42 expression as described in Materials and methods section. (B) Relative intensity of signals, after scan and software analyses (ImageQuant). Results are expressed as percentages of controls. PAM = pamidronate; $\quad C L O D=$ clodronate; $\quad \mathrm{IBAN}=$ ibandronate and $\mathrm{ZOLE}=$ zoledronate 


\section{DISCUSSION}

The high concentrations of growth factors in bone matrix provide a fertile 'soil' for metastatic breast cancer cells (hypothesis proposed by Paget, 1889). When tumour cells arrive in bone, a vicious cycle arises since they stimulate osteoclast-induced bone resorption, enhancing the supply of bone-derived growth factors in the bone microenvironment. This may explain why bone tissue is the most frequent organ in which breast cancers develop distant metastases (Boyce et al, 1999; Yoneda et al, 2000). IGFs are the most abundant growth factors stored in bone matrix (Mohan and Baylink, 1996) and, more importantly, are potent survival factors for a wide range of tumour cells, notably breast cancer cells (Dunn et al, 1997), by exerting both mitogenic and antiapoptotic effects (Osborne et al, 1990; Baserga et al, 1994). The role of IGF-I as a survival factor for cells in culture was first demonstrated in IL-3-dependent haemopoietic cells (Rodriguez-Tarduchy et al, 1992). Removal of IL-3 results in cell apoptosis, which can be blocked by adding IGF-I to cell cultures. In the same way, FGF-2 can stimulate cancer cell proliferation and prevent cell death (Miyake et al, 1997). There is thus substantial evidence to indicate that IGFs and FGF-2 are critical survival factors for cancer cells, and that metastases development is indeed dependent on such survival signals. We first examined the modulation of breast cancer cell survival in the presence of IGF-I, IGF-II, FGF-2 or EGF, and we confirmed that, except for EGF, these growth factors promoted MCF-7 and T47D cell survival in vitro under serum-free conditions. In agreement with other authors' data (McCarthy et al, 1989), we observed that IGF-II was about 10 -fold less potent than IGF-I to increase breast cancer cell survival under serum-free conditions.

Bisphosphonates are synthetic compounds that preferentially accumulate in bone (Sato et al, 1991) by their strong affinity for calcified matrix. They are powerful inhibitors of osteoclastmediated bone resorption (Fleisch, 1991, 1997a; Russell and Rogers, 1999), and they significantly reduce skeletal morbidity in advanced breast cancer patients (Body, 2000). Bisphosphonates can also decrease the number of bone metastases (Hall and Stoica, 1994; Powles et al, 2002). Moreover, we and others recently demonstrated that, in vitro, bisphosphonates irreversibly reduce breast cancer cell viability by inducing cell death, either by apoptosis or by direct cell necrosis (Fromigue et al, 2000; Senaratne et al, 2000; Jagdev et al, 2001a). The exact mechanism of action of bisphosphonates is unknown. We checked the hypothesis of a cation chelation by testing increasing concentrations of EDTA on MCF-7 cell viability and apoptosis. No significant effect was detected even at the highest concentration $\left(10^{-4} \mathrm{M}\right.$; data not shown). Recent data go along the same line (Jagdev et al, 2001a) and led us to discard the possibility that the observed effects are due to simple cation chelation by the bisphosphonates.

It is difficult to know or to evaluate the concentrations of bisphosphonates that are reached in the bone microenvironment in vivo. Studies in rats revealed that concentrations as high as $10^{-4} \mathrm{M}$ or $10^{-3} \mathrm{M}$ can be reached in resorption lacunae (Sato et al, 1991). The concentrations we chose $\left(10^{-6} \mathrm{M}\right)$ could thus be easily reached in the skeleton, and it did not induce strong toxicity in vitro as it can be observed for concentrations of $10^{-4}$ or $10^{-3} \mathrm{M}$ (Fromigue et al, 2000). We showed here that this relatively low concentration was able to block growth factors' effects, and to inhibit the 'protective' effect of growth factors on breast cancer cell survival. The effects of bisphosphonates that we observed were thus obtained with relatively low concentrations of bisphosphonates, in contrast to earlier works that reported the requirement for higher concentrations, between 20 and $1000 \mu \mathrm{M}$, to exhibit antitumour effects (Senaratne et al, 2000; Lee et al, 2001; Jagdev et al, 2001a).
Our hypothesis is thus that in bisphosphonate-treated patients, metastatic breast cancer cells in bone are influenced by various growth factors, which may promote cell survival and/or cell growth, but they can also be in contact with bisphosphonates that might induce their death. A 'competition' between these two opposite effects could thus modulate breast cancer cell proliferation and death. Very few data are available on the potential interactions between bisphosphonates and growth factors, but it was recently reported that administration of bisphosphonates to patients with bone metastases significantly decreases serum FGF-2 concentrations (Zimering, 2002). It has also been shown that pamidronate inhibits the effects of GH and decreases IGF-I levels in rats (Kapitola et al, 2000), or inhibits the effects of G-CSF on bone cells (Suzuki et al, 1999). Our first experiments showed that when both growth factors and bisphosphonates were simultaneously added to cell cultures, the stimulatory effects of growth factors on cell survival were markedly decreased (for IGFs) or even abolished (for FGF-2). The increased cell survival observed in IGFs-treated cells can be explained by an inhibition of apoptosis, confirmed for example by a decrease in the bax/bcl-2 ratio (Jung et al, 1996; Dunn et al, 1997; Xu et al, 1997). Bisphosphonates could counterbalance these protective effects of bone-derived growth factors on human breast cancer cell survival. On the other hand, we confirmed a time-dependent increase in caspases activity under bisphosphonate treatment, as previously described (Fromigue et al, 2000). This stimulation was almost completely abolished when MCF-7 cells were incubated with both growth factors and bisphosphonates.

In in vivo conditions, due to bisphosphonate-induced decrease in bone turnover, the release of bone-derived growth factors should be diminished, resulting in a less favourable microenvironment for cancer cells growth. This would come in addition to the inhibition by bisphosphonates of the protective effects of growth factors on cancer cells that we report here. Bisphosphonates and growth factors thus appear to be concurrent compounds for tumour cell survival in bone tissue. There might be a simple balance between opposite effects or a real antagonism between these two classes of compounds. We thus tried in the last part of this report to start to characterise such possible interactions. The exact intracellular mechanisms of action of bisphosphonates are still to be further delineated and our preliminary data could point to a new molecular mode of action of bisphosphonates.

In this study, we tested four structurally different bisphosphonates, known to exhibit variable potencies in bone resorption inhibition. Indeed, clodronate and pamidronate are bisphosphonates of first/second generations. In contrast, ibandronate and zoledronic acid are last generation bisphosphonates that represent the two most potent compounds (Hiraga et al, 2001; Jagdev et al, 2001a; Rosen et al, 2001; Body, 2003; Lipton, 2003). Despite their marked differences in potency to inhibit bone resorption in vitro or in vivo, we did not observe major differences between the potency of these four compounds in our in vitro experiments. It is now accepted that nitrogen-containing bisphosphonates can inhibit osteoclast activity through the mevalonate pathway (Luckman et al, 1998; Benford et al, 1999; van Beek et al, 1999; Coxon et al, 2000). In our model, it appears likely that modulations of the mevalonate pathway by nitrogen-containing bisphosphonates cannot entirely explain the effects we observed on human breast cancer cells since all four tested compounds reduced bone growth factors' effects on cell survival at about the same degree. Indeed, pamidronate, ibandronate and zoledronate are nitrogen-containing bisphosphonates, which interfere with the mevalonate pathway, whereas clodronate does not and is actually metabolised into a toxic ATP analogue (Frith et al, 1997). A common characteristic to these four structurally different compounds is evidently the presence of two phosphate groups, which could suggest that bisphosphonates could interact with intracellular phosphorylation signalling pathways (including kinases, phosphorylation reactions 
or phosphatase activities). Along that line, some authors already reported modulations of protein - tyrosine phosphatase activity by alendronate in osteoclasts (Schmidt et al, 1996) and of the MAPK pathway in osteoblasts by six different bisphosphonates (Plotkin et al, 1999). It is also well known that growth factors modulate cell metabolism through interactions with specific kinase receptors and intracellular signal transduction through MAPK or PI-3K pathways (Dufourny et al, 1997; Imai and Clemmons, 1999). We evaluated the phosphorylation state of JNK, ERK1/2 and p38 MAPK after incubation with bisphosphonates and/or growth factors. No modification in JNK and p38 phosphorylation levels was detectable by Western blot, but the ERK1/2 pathway was clearly affected, suggesting a modulation of cell survival and not a response to stress (Xia et al, 1995). As expected, FGF-2 induced a marked increase in ERK1/2 phosphorylation status but, interestingly, bisphosphonates decreased ERK1/2 phosphorylation and attenuated FGF-2 effects. Further experiments should evidently be performed, but these preliminary data suggest another possible mechanism of intracellular action of bisphosphonates.

In conclusion, in addition to the previously demonstrated direct 'antitumour' effects of bisphosphonates, the present report indicates that bisphosphonates might antagonise the stimulatory

\section{REFERENCES}

Adams JM, Cory S (1998) The bcl-2 protein family: arbiters of cell survival. Science 281: $1322-1326$

Azuma Y, Sato H, Oue Y, Okabe K, Ohta T, Tsuchimoto M, Kiyoki M (1995) Alendronate distributed on bone surfaces inhibits osteoclastic bone resorption in vitro and in experimental hypercalcemia models. Bone 16: $235-245$

Barnes DM (1988) Cells without growth factors commit suicide. Science 242: $1510-1511$

Baserga R, Sell C, Porcu P, Rubini M (1994) The role of the IGF-I receptor in the growth and transformation of mammalian cells. Cell Prolif 27: 6371

Benford HL, Frith JC, Auriola S, Monkkonen J, Rogers MJ (1999) Farnesol and geranylgeraniol prevent activation of caspases by aminobisphosphonates: biochemical evidence for two distinct pharmacological classes of bisphosphonate drugs. Mol Pharmacol 56: 131-140

Body JJ (2000) Current and future directions in medical therapy: hypercalcemia. Cancer 88: 3054-3058

Body JJ (2001) Bisphosphonates in the treatment of metastatic breast cancer. J Mammary Gland Biol Neoplasia 6: 477-485

Body JJ, Bartl R, Burckhardt P, Delmas PD, Diel IJ, Fleisch H, Kanis JA, Kyle RA, Mundy GR, Paterson AH, Rubens RD (1998) Current use of bisphosphonates in oncology. J Clin Oncol 16: 3890-3899

Body JJ (2003) Zoledronic acid: an advance in tumour bone disease and a new hope for osteoporosis . Exp Opin Pharmacother 4: 567-580

Boyce BF, Yoneda T, Guise TA (1999) Factors regulating the growth of metastatic cancer in bone. Endo Relat Cancer 6: 333-347

Coleman RE (2002) Efficacy of zoledronic acid and pamidronate in breast cancer patients: a comparative analysis of randomized phase III trials. Am J Clin Oncol 25: S25-S31

Coxon FP, Helfrich MH, Van't Hof R, Sebti S, Ralston SH, Hamilton A, Rogers MJ (2000) Protein geranylgeranylation is required for osteoclast formation, function, and survival: inhibition by bisphosphonates and GGTI-298. J Bone Miner Res 15: 1467-1476

Dufourny B, Alblas J, van Teeffelen HA, van Schaik FM, van der Burg B, Steenbergh PH, Sussenbach JS (1997) Mitogenic signaling of insulin-like growth factor I in MCF-7 human breast cancer cells requires phosphatidylinositol 3-kinase and is independent of mitogen-activated protein kinase. J Biol Chem 272: 31163-31171

Dunn SE, Kari FW, French J, Leininger JR, Travlos G, Wilson R, Barrett JC (1997) Dietary restriction reduces insulin-like growth factor I levels, which modulates apoptosis, cell proliferation, and tumor progression in p53-deficient mice. Cancer Res 57: 4667-4672

Fleisch H (1991) Bisphosphonates. Pharmacology and use in the treatment of tumour-induced hypercalcaemic and metastatic bone disease. Drugs 42: $919-944$ effects of growth factors on the proliferation of breast cancer cells and counterbalance their protective effects on breast cancer cell death. Changes in intracellular phosphorylation transduction pathways could partly explain our observations. Maybe importantly from a clinical point of view, these effects could contribute to the beneficial activity of bisphosphonates and appear to indicate that the mechanism of inhibition of tumour-induced osteolysis by bisphosphonates is much more complex than a 'simple' antiosteoclast activity. Our findings may thus represent a novel mechanism of action of bisphosphonates in the process of inhibition of tumour-induced osteolysis.

\section{ACKNOWLEDGEMENTS}

We thank Hoffmann-LaRoche (Basel, Switzerland) for grant support and for providing clodronate and ibandronate, and Novartis (Basel, Switzerland) for giving pamidronate and zoledronic acid. The study has also been supported by grants from the Fondation Medic, Fonds de la Recherche Scientifique Médicale (FRSM, convention 3.4563.02) and 'Les Amis de l'Institut Bordet'.
Fleisch H (1997a) Bisphosphonates: mechanisms of action and clinical use in osteoporosis - an update. Horm Metab Res 29: 145-150

Fleisch HA (1997b) Bisphosphonates: preclinical aspects and use in osteoporosis. Ann Med 29: 55-62

Frith JC, Monkkonen J, Blackburn GM, Russell RG, Rogers MJ (1997) Clodronate and liposome-encapsulated clodronate are metabolized to a toxic ATP analog, adenosine $5^{\prime}$-(beta, gamma-dichloromethylene) triphosphate, by mammalian cells in vitro. J Bone Miner Res 12: 1358 1367

Fromigue O, Body JJ (2002) Bisphosphonates influence the proliferation and the maturation of normal human osteoblasts. J Endocrinol Invest 25: $539-546$

Fromigue O, Lagneaux L, Body JJ (2000) Bisphosphonates induce breast cancer cell death in vitro. J Bone Miner Res 15: 2211-2221

Geier A, Haimshon M, Beery R, Hemi R, Lunenfeld B (1992) Insulinlike growth factor-1 inhibits cell death induced by cycloheximide in MCF-7 cells: a model system for analyzing control of cell death. In vitro Cell Dev Biol 28A: $725-729$

Hall DG, Stoica G (1994) Effect of the bisphosphonate risedronate on bone metastases in a rat mammary adenocarcinoma model system. J Bone Miner Res 9: $221-230$

Hauschka PV, Mavrakos AE, Iafrati MD, Doleman SE, Klagsbrun M (1986) Growth factors in bone matrix. Isolation of multiple types by affinity chromatography on heparin-Sepharose. J Biol Chem 261: 12665-12674

Hiraga T, Williams PJ, Mundy GR, Yoneda T (2001) The bisphosphonate ibandronate promotes apoptosis in MDA-MB-231 human breast cancer cells in bone metastases. Cancer Res 61: 4418-4424

Hortobagyi GN, Theriault RL, Lipton A, Porter L, Blayney D, Sinoff C, Wheeler H, Simeone JF, Seaman JJ, Knight RD, Heffernan M, Mellars K, Reitsma DJ (1998) Long-term prevention of skeletal complications of metastatic breast cancer with pamidronate. Protocol 19 Aredia Breast Cancer Study Group. J Clin Oncol 16: 2038-2044

Hughes DE, MacDonald BR, Russell RG, Gowen M (1989) Inhibition of osteoclast-like cell formation by bisphosphonates in long-term cultures of human bone marrow. J Clin Invest 83: 1930 - 1935

Hughes DE, Wright KR, Uy HL, Sasaki A, Yoneda T, Roodman GD, Mundy GR, Boyce BF (1995) Bisphosphonates promote apoptosis in murine osteoclasts in vitro and in vivo. J Bone Miner Res 10: 1478-1487

Imai Y, Clemmons DR (1999) Roles of phosphatidylinositol 3-kinase and mitogen-activated protein kinase pathways in stimulation of vascular smooth muscle cell migration and deoxyriboncleic acid synthesis by insulin-like growth factor-I. Endocrinology 140: $4228-4235$

Jagdev SP, Coleman RE, Shipman CM, Rostami-H A, Croucher PI (2001a) The bisphosphonate, zoledronic acid, induces apoptosis of breast cancer cells: evidence for synergy with paclitaxel. Br J Cancer 84: 1126-1134 
Jagdev SP, Purohit P, Heatley S, Herling C, Coleman RE (2001b) Comparison of the effects of intravenous pamidronate and oral clodronate on symptoms and bone resorption in patients with metastatic bone disease. Ann Oncol 12: 1433 - 1438

Janicke RU, Sprengart ML, Wati MR, Porter AG (1998) Caspase-3 is required for DNA fragmentation and morphological changes associated with apoptosis. J Biol Chem 273: $9357-9360$

Jung Y, Miura M, Yuan J (1996) Suppression of interleukin-1 betaconverting enzyme-mediated cell death by insulin-like growth factor. J Biol Chem 271: $5112-5117$

Kapitola J, Zak J, Lacinova Z, Justova V (2000) Effect of growth hormone and pamidronate on bone blood flow, bone mineral and IGF-I levels in the rat. Physiol Res 49: S101-S106

Lee MV, Fong EM, Singer FR, Guenette RS (2001) Bisphosphonate treatment inhibits the growth of prostate cancer cells. Cancer Res 61: $2602-2608$

Lin JH (1996) Bisphosphonates: a review of their pharmacokinetic properties. Bone 18: $75-85$

Lipton A (2003) Bisphosphonates and metastatic breast carcinoma. Cancer 97: $848-853$

Lowik CW, van der Pluijm G, van der Wee-Pals LJ, van Treslong-De Groot HB, Bijvoet OL (1988) Migration and phenotypic transformation of osteoclast precursors into mature osteoclasts: the effect of a bisphosphonate. J Bone Miner Res 3: 185-192

Luckman SP, Hughes DE, Coxon FP, Graham R, Russell G, Rogers MJ (1998) Nitrogen-containing bisphosphonates inhibit the mevalonate pathway and prevent post-translational prenylation of GTP-binding proteins, including Ras. J Bone Miner Res 13: 581 - 589

McCarthy TL, Centrella M, Canalis E (1989) Regulatory effects of insulinlike growth factors I and II on bone collagen synthesis in rat calvarial cultures. Endocrinology 124: $301-309$

Miyake H, Yoshimura K, Hara I, Eto H, Arakawa S, Kamidono S (1997) Basic fibroblast growth factor regulates matrix metalloproteinases production and in vitro invasiveness in human bladder cancer cell lines. J Urol 157: $2351-2355$

Mohan S, Baylink DJ (1996) Insulin-like growth factor system components and the coupling of bone formation to resorption. Horm Res 45: 59-62

Mundy GR (1991) Mechanisms of osteolytic bone destruction. Bone 12: S1 S6

Murakami H, Takahashi N, Sasaki T, Udagawa N, Tanaka S, Nakamura I, Zhang D, Barbier A, Suda T (1995) A possible mechanism of the specific action of bisphosphonates on osteoclasts: tiludronate preferentially affects polarized osteoclasts having ruffled borders. Bone 17: 137-144

Nishikawa M, Akatsu T, Katayama Y, Yasutomo Y, Kado S, Kugal N, Yamamoto M, Nagata N (1996) Bisphosphonates act on osteoblastic cells and inhibit osteoclast formation in mouse marrow cultures. Bone 18: 9 14

Osborne CK, Clemmons DR, Arteaga CL (1990) Regulation of breast cancer growth by insulin-like growth factors. J Steroid Biochem Mol Biol 37: 805-809

Paget S (1889) The distribution of secondary growth in cancer of the breast. Lancet 1: $571-573$

Paterson AHG, Powles TJ, Kanis JA, McCloskey E, Hanson J, Ashley S (1993) Double-blind controlled trial of oral clodronate in patients with bone metastases from breast cancer. J Clin Oncol 11: 59-65

Plotkin LI, Weinstein RS, Parfitt AM, Roberson PK, Manolagas SC, Bellido T (1999) Prevention of osteocyte and osteoblast apoptosis by bisphosphonates and calcitonin. J Clin Invest 104: $1363-1374$

Powles T, Paterson S, Kanis JA, McCloskey E, Ashley S, Tidy A, Rosenqvist K, Smith I, Ottestad L, Legault S, Pajunen M, Nevantaus A, Mannisto E, Suovuori A, Atula S, Nevalainen J, Pylkkanen L (2002) Randomized, placebo-controlled trial of clodronate in patients with primary operable breast cancer. J Clin Oncol 20: 3219-3224

Quinn KA, Treston AM, Unsworth EJ, Miller MJ, Vos M, Grimley C, Battey J, Mulshine JL, Cuttitta F (1996) Insulin-like growth factor expression in human cancer cell lines. J Biol Chem 271: 11477-11483
Rodriguez-Tarduchy G, Collins MK, Garcia I, Lopez-Rivas A (1992) Insulin-like growth factor-I inhibits apoptosis in IL-3-dependent hemopoietic cells. J Immunol 149: 535-540

Rosen LS, Gordon D, Kaminski M, Howell A, Belch A, Mackey JA, Apffelstaedt J, Hussein M, Coleman RE, Reitsma DJ, Seaman JJ, Chen BL, Ambros Y (2001) Zoledronic acid versus pamidronate in the treatment of skeletal metastases in patients with breast cancer or osteolytic lesions of multiple myeloma: a phase III, double-blind, comparative trial. Cancer J 7: $377-387$

Russell RG, Rogers MJ (1999) Bisphosphonates: from the laboratory to the clinic and back again. Bone 25: 97-106

Sahni M, Guenther HL, Fleisch H, Collin P, Martin TJ (1993) Bisphosphonates act on rat bone resorption through the mediation of osteoblasts. J Clin Invest 91: 2004-2011

Sato M, Grasser W, Endo N, Akins R, Simmons H, Thompson DD, Golub E, Rodan GA (1991) Bisphosphonate action. Alendronate localization in rat bone and effects on osteoclast ultrastructure. I Clin Invest 88: $2095-2105$

Schmidt A, Rutledge SJ, Endo N, Opas EE, Tanaka H, Wesolowski G, Leu CT, Huang Z, Ramachandaran C, Rodan SB, Rodan GA (1996) Proteintyrosine phosphatase activity regulates osteoclast formation and function: inhibition by alendronate. Proc Natl Acad Sci USA 93: $3068-3073$

Selander K, Lehenkari P, Vaananen HK (1994) The effects of bisphosphonates on the resorption cycle of isolated osteoclasts. Calcif Tissue Int 55: $368-375$

Senaratne SG, Pirianov G, Mansi JL, Arnett TR, Colston KW (2000) Bisphosphonates induce apoptosis in human breast cancer cell lines. $\mathrm{Br} J$ Cancer 82: 1459-1468

Siwek B, Lacroix M, De Pollak C, Marie P, Body JJ (1997) Secretory products of breast cancer cells specifically affect human osteoblastic cells: partial characterization of active factors. J Bone Miner Res 12: 552 560

Suzuki M, Adachi K, Sugimoto T, Nakayama H, Doi K (1999) The development of bone changes induced in rats by recombinant human granulocyte colony-stimulating factor is suppressed by bisphosphonate. Histol Histopathol 14: 679-686

Taube T, Elomaa I, Blomqvist C, Beneton MN, Kanis JA (1994) Histomorphometric evidence for osteoclast-mediated bone resorption in metastatic breast cancer. Bone 15: 161-166

Theriault RL, Lipton A, Hortobagyi GN, Leff R, Gluck S, Stewart JF, Costello S, Kennedy I, Simeone J, Seaman JJ, Knight RD, Mellars K, Heffernan M, Reitsma DJ (1999) Pamidronate reduces skeletal morbidity in women with advanced breast cancer and lytic bone lesions: a randomized, placebo-controlled trial. Protocol 18 Aredia Breast Cancer Study Group. J Clin Oncol 17: 846-854

van Beek E, Pieterman E, Cohen L, Lowik C, Papapoulos S (1999) Farnesyl pyrophosphate synthase is the molecular target of nitrogencontaining bisphosphonates. Biochem Biophys Res Commun 264: $108-111$

Vitte C, Fleisch H, Guenther HL (1996) Bisphosphonates induce osteoblasts to secrete an inhibitor of osteoclast-mediated resorption. Endocrinology 137: $2324-2333$

Xia Z, Dickens M, Raingeaud J, Davis RJ, Greenberg ME (1995) Opposing effects of ERK and JNK-p38 MAP kinases on apoptosis. Science 270: $1326-1331$

Xu F, Gardner A, Tu Y, Michl P, Prager D, Lichtenstein A (1997) Multiple myeloma cells are protected against dexamethasone-induced apoptosis by insulin-like growth factors. Br J Haematol 97: 429-440

Yoneda T, Williams P, Myoi A, Michigami T, Mbalaviele G (2000) Tumor bone diseases and osteoporosis in cancer patients, In: Cellular and Molecular Mechanisms of Development of Skeletal Metastases, Dekker M (ed) pp 41-69. New York, NY, USA

Zimering MB (2002) Effect of intravenous bisphosphonates on release of basic fibroblast growth factor in serum of patients with cancer-associated hypercalcemia. Life Sci 70: 1947 - 1960 